This article illustrates the English approach to planning controls which is based upon a broad concept of public policy and utilizes a more extensive administrative hierarchy. Besides describing methods sharply contrasting with our own regulatory techniques, the authors present a fascinating recapitulation of the interweaving of those physical, social and economic aspects of East Sussex which provide the raw materials for the planner.

\title{
VILLAGE PLANNING IN EAST SUSSEX
}

\author{
L. S. JAY $\dagger$ \\ K. D. FINES $\ddagger$ \\ J. FURMIDGE $\dagger \dagger$
}

It has been called "The Big Street"-the 600-mile stretch of the eastern seaboard of America from Maine to Virginia. Christopher Tunnard claims that there is only one remotely similar urban region in the world-the North Atlantic European area whence the founders of the newer area came.

The 250 mile British section of the European "big street" runs from Lancashire in the north through the "black country" of the midlands then to the metropolis of London and terminates on the south coast in the counties of Kent and East Sussex. Professor Eva G. R. Taylor appropriately named this area the "industrial coffin"- -not only because of its shape on the map. Urban sprawl, traffic congestion, commuting, overcrowding, the decay of the town centers, the blurring of the distinction between town and country, the supercession of the local by regional loyalties are indigenous to this, as well as the American, urban region. However, Britain can claim perhaps two

$\dagger$ A.M.I.C.E., A.M.T.P.I., A.M.I. Mun. E. County Planning Officer, East Sussex County Council. Associate Member, Institute of Civil Engineers. Associate Member, Town Planning Institute. Associate Member, Institute of Municipal Engineers. Formerly with Isle of Wight County Council, Norfolk County Council.

$\mp$ A.M.P.T.I., A.I.L.A. Senior Assistant County Planning Officer, East Sussex County Council. Associate Member, Town Planning Institute. Associate, Institute of Landscape Architects. Formerly with Berkshire County Council, Hove Borough Council.

† A.M.T.P.I. Senior Planning Assistant, East Sussex County Council. Associate Member, Town Planning Institute. Formerly with Surrey County Council.

1 Tunnard. The Landscape of the Big Street, 61 The LISTENER 124 (1956). 
advantages-a twenty year lag in the escalation towards ultimate chaos and a twenty year lead in comprehensive statutory planning. Although town and country planning has traditionally been a local function, the national government has now added the role of positive planning to its legislative, judical and coordinating functions by producing regional studies for Scotland, North East England and, more recently, South East England. The first two studies are aimed at the regeneration of areas of periodic unemployment and consequent depopulation; the third, with which East Sussex is vitally concerned, is aimed at the control of the relentless growth of the urban region centered in London. ${ }^{2}$

Despite the trend toward regional planning, county and county borough councils remain the statutory planning authorities primarily responsible for the preparation of development plans ${ }^{3}$ and for day to day development control. ${ }^{\sharp}$ These development plans are subject to the approval of the Minister of Housing and Local Government ${ }^{5}$ and must be reviewed by local planning authorities at least once every five years. $^{6}$ Such flexibility, which is one of the distinctive features of the British system, ensures that the plans are adapted to meet advances in technology and the changing goals of society.

The county plans coordinate the detailed layout plans ${ }^{8}$ which are prepared for the residential, town center and other zones or "environmental areas," ${ }^{8}$ in the form of either "comprehensive development area

2 Ministry of Housing and Local Governament [of Great Britain], The Soutr EAST Study, 1961-1981 (1964), envisages that the population of the study area, which lies roughly southeast of a line from Southampton to the Wash, will grow by $3,500,000$ by 1981 . It is proposed that the population of London should be stabilized, and that three new cities (large enough to act as countermagnets) should be created beyond the influence of the capital. One city would be related to the deep water port of Southampton; the others would be located at nodal points on the national motorway system-at Newbury in Berkshire and at Bletchley in Buckinghamshire. In addition, six existing towns are selected for major expansion and twelve for minor expansion.

It is proposed that the new cities and expanded towns should accommodate $1,250,000$ of the total increase and that the balance of $2,250,000$ should be apportioned among the administrative counties and county boroughs, leaving the authorities concerned to propose the manner in which their share should be distributed.

3 Town and Country Planning Act of 1962,10 \& 11 Eliz. 2, c. 38, § 4.

4 Town and Country Planning Act of 1962, 10 \& 11 Eliz. 2, c. 38, §14(2) (b).

5 Town and Country Planning Act of $1962,10 \& 11$ Eliz. 2, c. $38, \S 5$.

6 Town and Country Planning Act of 1962, 10 \& 11 Eliz. 2, c. $38, \S 6$.

7 The "county map" (to a scale of one inch to one mile) and the "written statement" are the overall policy documents for administrative counties. They indicate the proposals for the distribution of population and industry, the system of communications, and the protection of natural resources and amenities. Statutory "town maps" (to a scale of six inches to one mile) are prepared within the framework of the "county map." The town maps establish an urban road network and a broad pattern of primary use zones and define sites for essential projects.

8 These plans are set to a scale of twenty-five or fifty inches to a mile.

9 Ministry of Transport [of Great Britain], Traffic in Towns (1963). 
maps" requiring ministerial approval or informal plans requiring only the approval of the local planning authority. ${ }^{10}$ The "village plan" is just such an informal plan and represents a peculiarly English form of "planned unit development."

The village has a genius loci which makes it instantly recognizable; yet it defies precise definition. The traditional village of fond memory is a settlement which physically lies indeterminately in size between the hamlet and the small town; which economically is directly or indirectly concerned with agriculture; and which socially is an integrated community governed by an unwritten feudal code. Dr. Thomas Sharp said that in essence the difference between the village and the town was the difference between simplicity and complexity. ${ }^{11}$

For over one hundred years, however, the village has been in a state of metamorphosis. The consequences of the Industrial Revolution-the development of the factory system, the repeal of the Corn Laws, the switch to grain imports from North America, the progressive mechanization of agriculture-led to the emigration of millions of country folk to the new towns, or to the New World. At the same time, because of the appalling conditions in the industrial centers and the opportunity afforded by the new forms of transport, there was an exodus of urban population from the congested towns and cities to the countryside. The nouveaux riches set the trend in the nineteenth century and they were followed by the middle class and, later, by the artisan class. As a result, a secondary pattern of settlement was superimposed on the original or primary pattern. The railway created the one class "dormitory" settlement, which grew up around stations intended to serve the nearest villages. In the inter-war period the motor vehicle created the notorious ribbon development-a tentacular growth spreading out along the main roads linking town with village and forming the advance guard of the creeping anonymous suburbs that finally engulfed the villages nearest to the towns. ${ }^{12}$

10 Because of the pressure of work in his department and the consequent delay in the approval of statutory plans, the Minister is encouraging planning authorities to prepare the informal type of plan. He has indicated that he will take the informal plan into account if presented in evidence at any public inquiry he may hold when there is an appeal from the refusal of the planning commission.

11 Sharp, Anatomy of the Village (1946).

12 Villages within commuter range of the towns have experienced not only physical change but a profound upheaval in their socio-economic structure. The primary agricultural population has gradually been dominated, or even replaced, by immigrants who in the main are retired people or commuters with no connection with the land. In East Sussex there are some 240 villages and hamlets, but no more than fifty are now predominantly agricultural.

The newcomers have occupied the old cottages as well as the new houses. The former are in great demand. In the fashionable villages the meanest hovel is at a premium and thousands of pounds may be spent on restoration and modernization. Old barns and oast houses, in fact any building with a trace of antiquity-even dis- 
Many of the villages which lie beyond commuter range of the larger towns have experienced a vicious circle of decay. ${ }^{13}$ Emigration to the towns, particularly by the younger generation, brought the population to a level where services, no longer economical, were lost one by one-the daily bus service, the general store, the village school, sometimes even the church. Further depopulation inevitably followed. In some cases decay has already proceeded to its inevitable conclusion. The village has disappeared.

\section{Planning Policy in East Sussex}

\section{A. Village Planning Policy}

In East Sussex it is acknowledged that the "village" has an important role to play in planning policy. This concept is not designed to limit the size of a settlement, but to serve as a guide to the optimum rate of growth. Thus by controlling development, it is believed that neither architectural character nor social life will be disrupted by the changes of a single decade. In order to implement this policy, the rural settlements in East Sussex have been classified as follows:

(a) Major Expansion: Settlements selected as "growth points" where major expansion will be encouraged.

(b) Minor Expansion: Settlements where some expansion, particularly for local housing needs, will be permitted.

(c) Rounding-Off: Settlements where development will be contained within the framework of the existing builtup area.

(d) Infilling: Settlements where development will be permitted only by infilling sites on existing street frontages.

(e) Restricted: Settlements where development will be permitted in the form of single houses or small groups only if an essential local need can be established. ${ }^{4}$

used Victorian railway stations-are eagerly sought for conversion. The newcomers are inveterate preservationists, whether they live in old cottages or new estates. Many of the founder members of the young "preservation societies," who campaign against spoilation by further development, occupy the ugly suburban houses and bungalows that have already detracted from the character of the old villages.

13 It is a paradox that the process of decay is not confined to the remoter parts of Britain, such as Devon and Wales, but has been experienced even within the growing urban region centered on London. During the 1951-1961 intercensal period, East Sussex increased its population by eleven percent; but the growth continued to be in those towns and villages along the main lines of communication, particularly between London and the coast. Villages no more than two or three miles away continued to decline. In fact, of the 127 rural parishes fifty-seven declined or remained static.

14 Pending the preparation of village plans, a tentative estimate of optimum population at the end of the plan period has been made for each settlement. The estimate is made in light of the overall increase proposed in the South East Study and the basic survey information already available. Village plans are being prepared, initially, for settlements in the first two categories and for those of great beauty or historic value. 
Villages selected as "growth points" are generally those which have good accessibility, adequate public utility services, an ability to accommodate expansion without detriment to landscape or agricultural values, and which have demonstrated-by a history of population growth, a balanced age and social structure, and an active community life-a capacity to absorb a considerable increase in population. In contrast, "restricted" settlements are usually small villages or hamlets where even infilling developments would be unacceptable because of unique architectural character, traffic dangers or the absence of essential services.

One objective of planning policy is to avoid the "preserve-at-allcosts" attitude which tends to make the village a museum exhibit and to put the planner in the role of a curator. Many people of the preservation school fail to observe that the traditional village is attractive because it is the product of centuries of gradual growth and change. Each age-Saxon, Mediaeval, Tudor, Georgian, even the muchmaligned Victorian-has left its imprint in the street plan or street picture, often contrasting with but always contributing to what has gone before. There is no a priori reason why we, in this age, should ossify the village. Thus, all that East Sussex planning seeks to maintain is the village "environment": a small integrated community, the proximity of open country, and simplicity in architectural form.

\section{B. The Systematic Method}

The development of a systematic approach to town and village planning, which takes full advantage of the modern techniques of aerial survey, photogrammetry, electronic data processing, microphotography and advanced statistical methods, distinguishes the work of the Planning Department of East Sussex. Although "village plans" are being prepared by most county councils, Professor Daniel $R$. Mandelker is of the opinion that "East Sussex stands almost alone in attempting a detailed field investigation of its rural community structure." ${ }^{15}$

Before any work is done in the field, an aerial survey of the particular planning area is undertaken. The ordinance survey maps are then brought up to date from the aerial photographs by photogrammetry. The photographs, which are in stereo pairs, are later used for site contouring and for detailed survey work.

Next a survey team equipped with the revised maps undertakes a comprehensive community survey in accordance with a detailed instruction manual. This survey is in two parts. The first consists of

15 Mandelker, Green Belts aNd Urban Growth 14 (1962). 
a physical survey of land use, age and condition of buildings and floor space, supplemented by transportation and other special surveys. The second is a social survey involving an interview at every house, shop and place of employment which provides information on population, occupation, employment, journey to work, vehicle ownership, housing conditions, immigration statistics, retail trade and community life. ${ }^{16}$

As the survey progresses completed questionnaires are returned to headquarters where the data is coded by reference to a coding manual and transferred to eighty-column punched cards. Upon completion these cards are processed by electronic computer in accordance with a predetermined standard program. As many as two hundred analysis tables giving a detailed record of every aspect of the community will then be available to the planning team which takes over the next stage of the process.

The planners' first objective is to formulate a development policy for the planning area. This objective is approached from two different angles: (a) a physical approach which determines the extent to which each village could be permitted to expand and establishes an ultimate development area or "envelope"; (b) a socio-economic approach which seeks to establish the extent to which each settlement ought to be allowed to expand during the plan period. The first approach is based upon a rigorous landscape survey, conducted by a landscape architect/planner, involving an evaluation of landscape and townscape and a study of topography, agricultural land values and the economics of public services. The second approach is based on the factors revealed by the community survey analysis such as population trends, age and social structure, employment and immigration factors.

The planners' second objective is to calculate the detailed requirements which would provide the necessary houses, schools, shops, industries, open spaces and many other land uses for the proposed population, and then to coordinate these requirements within a rational road network so as to design a satisfactory environment for human activities.

\section{Settlement Cluster Planning}

The problem of maintaining growth while retaining the village environment can be solved by an organic system of "settlement cluster planning," in other words by designing a hierarchy of planned units.

${ }^{16} \mathrm{~A}$ survey of this type was completed about ten years ago on a $100 \%$ basis for every small town, village and hamlet in the county, and provides a valuable base from which to measure physical and social changes revealed by subsequent surveys, Jay \& Hirsch, Rural Community Structure, in EAST Sussex CounTY CouncIL DEvelopMent Plan, SURvey REPoRt A (1953). It has been called a "twentieth-century Domesday survey." 
At the lowest level each unit would be a complete organism, but the units can be repeated to form interrelated groups of complex higher organisms. (Figure 1 illustrates the principle.)

An existing village may be expanded in the form of a series of small housing units or "building clusters" each consisting of a group of dwellings built around a small green or paved space, and each forming a complete composition but capable of interlocking with additional units in accordance with a planned program of development. This principle can, of course, be adapted for a completely new village.

A more complex unit may be formed by a group of villages planned around a parent town as a "settlement cluster." For example, an existing town and its dependent villages may be planned as a cluster-offering a choice of urban or village environment-where the size of the villages is no longer determined by agricultural needs but by the employment capacity of the town. The distance between the villages and the parent town would thus be governed by the journey to work. ${ }^{17}$ Such a distance is certainly less than that traveled from the suburbs of a large city into its center with the added advantage that the journey is made on uncongested roads through open country.

The optimum distribution of settlements within the cluster depends very much on the topography. In undulating wooded countryside the villages can be close together and still possess a rural character. In East Sussex some of the villages which are about four miles from a town are being planned not only as dormitories but as local shopping, employment and educational centers for the smaller villages and hamlets which lie further afield. This idea is designed to arrest the process of decay in the less accessible areas.

When the spacing around the parent town becomes very close, the villages become virtually urban neighborhoods. Indeed, Professor C. B. Fawcett of London University made an eloquent plea for the division of towns into "vills," each with a population between 1,200 and $2,400 .{ }^{18}$ Vills would be large enough to support a primary school but small enough to ensure an integrated community. ${ }^{19}$ Moreover, Professor Colin Buchanan's idea ${ }^{20}$ of dividing towns into "environmental areas" within which all extraneous traffic is prohibited could be easily applied to the vill.

17 A study of workplace movement over the whole of East Sussex shows that the modal distance traveled to work is about four miles, and this is generally accepted as the maximum distance between the villages selected as growth points and the parent town. Within this limit car commuters are able to return home during the lunch hour, cycling to work is possible and nobody needs spend more than half an hour on the journey between home and workplace. 1945).

is Fawcett, A Restdential Unit for Town and Country Planning (new ed.

20 Ministry of Transport, op. cit. supra note 9. 
Another type of plan involves a number of settlement clusters related to a city which form a city region or "urban galaxy." Here the spacing should permit commuting by fast train from town to city or from one town to another in order to achieve balanced employment on a regional basis. ${ }^{21}$ A variant of the city region plan involves the orderly development of a cluster of complete towns, to which is added at the appropriate time a city nucleus consisting of a regional shopping center and possibly a major industrial and commercial center.

\section{Village Ciuster Plan for Worter Parise}

In East Sussex there are a number of examples of "settlement cluster planning" in which a town and its related villages are planned as a unit. The various features of the plan for Worth Parish-from the overall plan for a cluster of villages to the detailed design for a new residential unit-provide one of the best illustrations. ${ }^{22}$

\section{A. The Problem}

Worth, one of the largest rural parishes in the county, lies in the northwest corner of East Sussex on the northern slopes of the Forest Ridge of the High Weald. Much of this stretch of moor and woodland country is unspoiled by building development and of great landscape value. But Worth is only twenty-five miles from London and lies just east of the trunk road and the electrified railway between the capital and the coast at Brighton. Thus, over the past century suburban sprawl creeping down the "transport corridor" has infiltrated the northern part of the parish. Where once there were isolated hamlets and farmsteads, there is now a confused pattern of "suburban villages" (Copthorne and Crawley Down), forest clearing settlements (Furnace Wood and Cuttinglye Wood), the traditional village of Turners Hill and the hamlet of Worth, the old parish center. All are linked by ribbon and sporadic development. Remarkably however, the area has not been completely spoiled by the unplanned growth.

Since the war the pressure for development in this corner of East Sussex has increased ${ }^{23}$ because of: (a) the restrictive policy within

21 The analysis of workplace movement referred to in note 17 supra, suggests that the rail journey time should not exceed one hour, which is equivalent to a maximum diameter for the region of about fifty miles.

22 It should be emphasized, however, that the proposals have not yet been considered by the local authorities concerned.

23 In 1960 the county council, as a defensive measure, sought to designate an area within a five mile radius of Crawley (including Worth Parish) as a green belt for the new town. Even though the council had acted on the advice of the officers of the Ministry of Housing and Local Government, the Minister, himself, rejected the proposal mainly on the grounds that the existing development control machinery was adequate. It was decided, therefore, to prepare a comprehensive plan for Worth. 
the London green belt to the north; (b) the development of nearby Crawley in West Sussex as one of the new towns for the reception of London overspill; (c) the decision to make Gatwick, just over the Surrey border, London's second airport.

\section{B. The Survey}

In 1963 a systematic program was adopted for Worth. The community survey revealed that, since the basic survey in 1952, the population of the "suburban villages" had increased substantially. ${ }^{24}$ Contrary to expectations, the landscape survey showed that the parish could still absorb a considerable increase in population, mainly at Crawley Down and Copthorne, without detriment to amenity or to agriculture.

\section{The Plan}

(An outline is shown in Figure 2.) The main proposals for the village cluster plan are as follows:

(a) Residential Development: Each settlement is to retain its own identity while future growth is concentrated at Crawley Down and Copthorne.

(b) Population:

\begin{tabular}{lccc} 
& $\begin{array}{c}\text { Category } \\
\text { (described in }\end{array}$ & Population & Population \\
& I, A above) & 1963 & 1981 \\
Crawley Down & $\mathrm{a}$ & 1,550 & 4,100 \\
Copthorne & $\mathrm{a}$ & 2,550 & 4,050 \\
Turners Hill & $\mathrm{c}$ & 500 & 600 \\
Furnace Wood & $\mathrm{d}$ & 250 & 300 \\
Cuttinglye Wood & $\mathrm{d}$ & 150 & 200 \\
Worth & $\mathrm{e}$ & 100 & 100 \\
Dispersed Remainder & $\mathrm{e}$ & 1,500 & 1,500 \\
\multicolumn{1}{c}{$\quad$ Parish Total } & & $\underline{6,600}$ & 10,850
\end{tabular}

(c) Function: The villages should remain predominantly residential. ${ }^{25}$

(d) Programing: The rate of growth will be carefully controlled by designating the order in which the housing

24 The population of Crawley Down had increased by $63 \%$ (from 950 to 1,550 ) and that of Copthorne had increased by $104 \%$ (from 1,250 to 2,550 ).

25 Crawley New Town should remain the primary employment, shopping and entertainment center, with the older town of East Grinstead, to the east, as a secondary center. Provision will be made at Crawley Down and Copthorne for local service industry, shops and primary schools. 
units are to be developed in the respective village plans. In no case will the ultimate village "envelope" be completely developed during the plan period.

(e) Communications: The outline plan indicates new regional distributor roads between London and the coast at Brighton and Eastbourne, to the west and east of the parish respectively.

A network of primary distributor roads is proposed to link the villages with one another, with the regional distributors and with Crawley and East Grinstead. Creation of the network can be achieved by improving extant roads.

It is hoped that an increase in population would enable the branch railway line between Crawley, Crawley Down, and East Grinstead, which has been threatened with closure, to remain in operation.

(f) Landscape: Every effort would be made to preserve and to enhance the woodland character of the area by confining its principal uses to agriculture, forestry and recreation.

\section{Planned Unit Development at Crawley Down: The Design Process}

Having established that certain areas are suitable for expansion and knowing from previous processes what population increase and new services including community facilities should be accommodated therein, the village planner begins "the design process." This process has been explained "as a series of subconscious conversations which a planner has with himself." 26 In this article we shall attempt an explanation of the process using the village of Crawley Down as a reference point.

\section{A. Village Features}

The design process begins with an appraisal of the existing village structure which is intended to define those features of the physical environment to which the new design might be related. In the past the traditionally simple ground plan of the true Sussex village, usually focussed on the village green, has been either linear or squared with minor variations, including cross roads. (See Figure 3.)

A physical examination of Crawley Down (see Figure 4) reveals a relatively compact settlement of later origin than the traditional Sussex village. Crawley Down is set in woodland with a focus on the village green at which are centered community facilities including shops and a railway station. The village green, as an enclosure, is

26 Remarks of B. Kenneth Johnstone, quoted in Srmonds, LANDSCAPE ArchitecTURE (1961). 
probably the most interesting feature of the townscape, which otherwise lacks visual interest since a roadside ribbon development produces a monotony of building form, a contorted road pattern lacking any coherence, and an absence of contrast and traditional village simplicity. Thus the resultant design should attempt to improve upon the previous low standard of townscape, and maximum linkage (preferably pedestrian) should be achieved with the village green.

\section{B. Site Appraisal}

The next planning step is to examine the land intended for village expansion in order to check its qualities before establishing a coherent design. This will involve a systematic accumulation of the following data:

(a) Contour Information: Usually this information may be extracted from aerial photographs by photogrammetry.

(b) Vegetation: A study of areas worth preserving with a note of marginal cover not necessarily worth preserving.

(c) Water Areas: A note of ponds, streams, lakes and of the extent to which they might be expanded by taking new surface water drainage.

(d) Special Features: Including topographical features which should be preserved in the layout.

(e) Good and Bad Views: Both into and out of the site.

(f) Possible Pedestrian and Vehicular Links: A study of links from the site to the village and notes of the condition and suitability of outside link points.

(g) Boumdary Notes: Location of walls, fences, hedgerow belts.

(h) Surrounding Property: Community survey information and notes of surrounding uses, location of decaying property, heights, etc. If it should prove necessary to demolish occupied property, the community survey will reveal occupancy details.

(i) Location of Overhead Electricity Lines: Ordinance survey will locate routes and the position of larger towers. Voltage and clearances required by the electricity authority will be noted.

(j) Location of Public Rights of Way: Examination of county records and site inspection noting condition and use.

(k) Examination of Large Scale Aerial Photographs: This procedure is useful for obtaining detailed information on vegetation and existing agricultural use (important data for effective programing). 
The information which is accumulated is then transferred to a site appraisal plan (Figure 5) and tentative road and pedestrian links are sketched on with suggestions for new uses on the site such as schools and shopping.

\section{Developing a Theme}

The first thoughts on a possible development theme for the new area will now appear to the planner. Creation of the theme initiates a gradual process aimed at relating an emergent urban environment as closely as possible to its natural predecessor. An approach now being developed in this county is to view the site area as one large cell into which will fit a number of smaller cells. This cellular structure may be developed to include the whole range of uses likely to arise on the site and can incorporate a wide measure of pedestrian/vehicular segregation. It is then a simple matter to interrelate the various smaller cells (see Figure 6) and provide the "open-ended" aspects of design which are intended to accommodate the future changes no one is able to project with precision. This creative analysis thus develops a theme or structure. In the Crawley Down expansion, the structure is organized on the basis of two major pedestrian walks related to the village green and school with subsidiary pedestrian offshoots serving the dwelling clusters. Local shops are provided along the pedestrian routes (see Figure 6).

\section{Site Organization}

Having established the layout theme, the planner then applies it to the site in order to perpetuate the best characteristics of the village townscape. The theme for Crawley Down is guided by the following: (a) layout and design of the new residential area should retain village scale; (b) the materials used in the dwelling construction should be sympathetic to those existing in the village with special attention paid to the design of courts, greens, fencing, walls and street furniture. But such a program is best achieved not by rigidly planning the specific date of release of certain areas, but by loosely indicating the order in which the land might be released-based upon agricultural criteria and a "pincer" movement towards the center of the site.

\section{ConClusion}

Based upon a comparative analysis of the totality of settlements which together comprise the county of East Sussex, as well as their groupings and functional relationships, an attempt is being made to create a framework within which it will be possible to preserve the 
character of rural settlement and of rural landscape despite the pressure of population and the high mobility of a motorized society. By using the systems approach which provides for continuous observation, analysis and feedback of information, the planner can best provide for exigencies in community development. Essentially, the planner provides a strategic framework within which other people can operate. It is important to recognize, however, that at all times the land itself is physically occupied and that within it there is an evolutionary situation over which the designer has no control. It is possible that, in an effort to control the situation, the planner may impose too many restraints and thereby destroy the possibilities of development within the framework of a particular design. This temptation must be avoided for the planner must always preserve the possibility of future development and change.

In East Sussex we see planning as a dynamic process within which the physical pattern for the future, reflected in the plans that we prepare, is a valuable and essential element but not a fixed one. The village communities are encouraged to take part in the process by being invited to meetings where the proposed plans are discussed. Speaking generally, our efforts have been welcomed, by the rural community itself, by the authorities called upon to provide and program essential public services, and by developers.

It may be more difficult to achieve coherent and satisfying buildings and group design of buildings than it is to achieve a satisfactory layout on the land. This is due to the fact that appreciation of design is so closely related to the environment inherited from the immediate past, and to the population's educational background. In addition, the shared powers of local government make it difficult for the planner to coordinate the design of buildings. However, to the extent that planning focuses the whole community's attention on the design goal, it will ease the process of coordination and help us achieve a physical environment which reflects a sense of "wholeness." 
Site Planning Diagrams

Nos. 1 THROUGH 7 

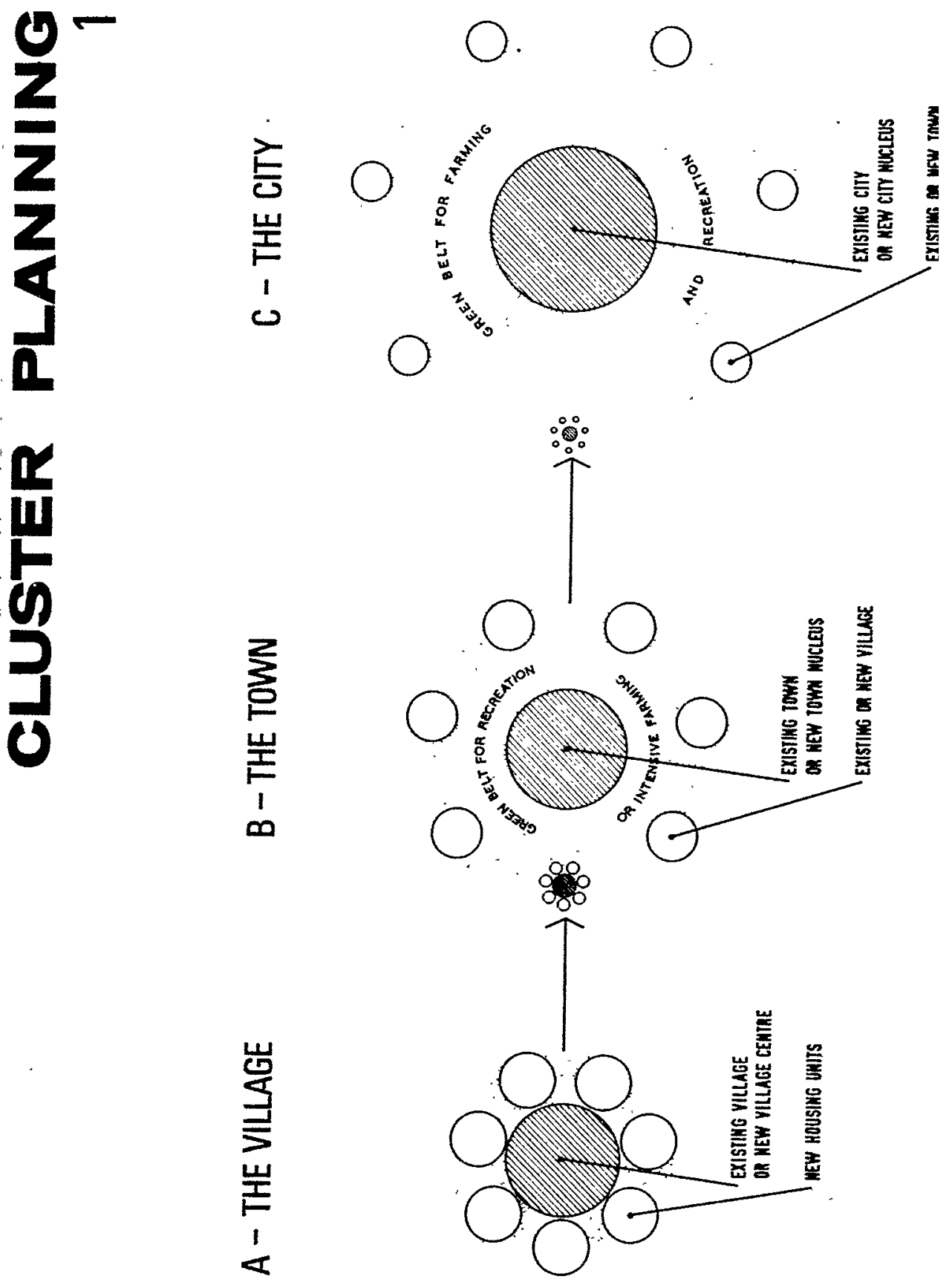


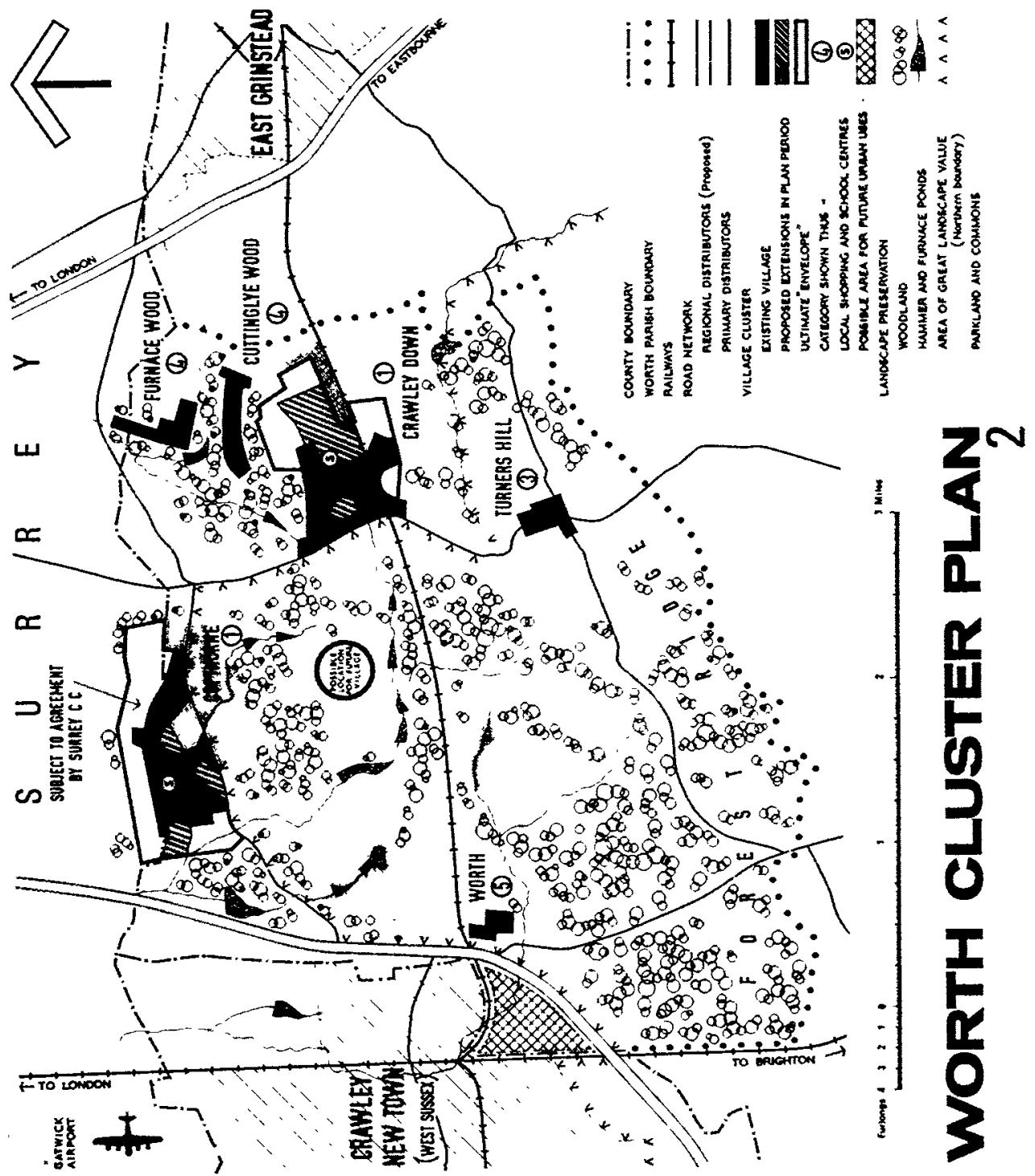



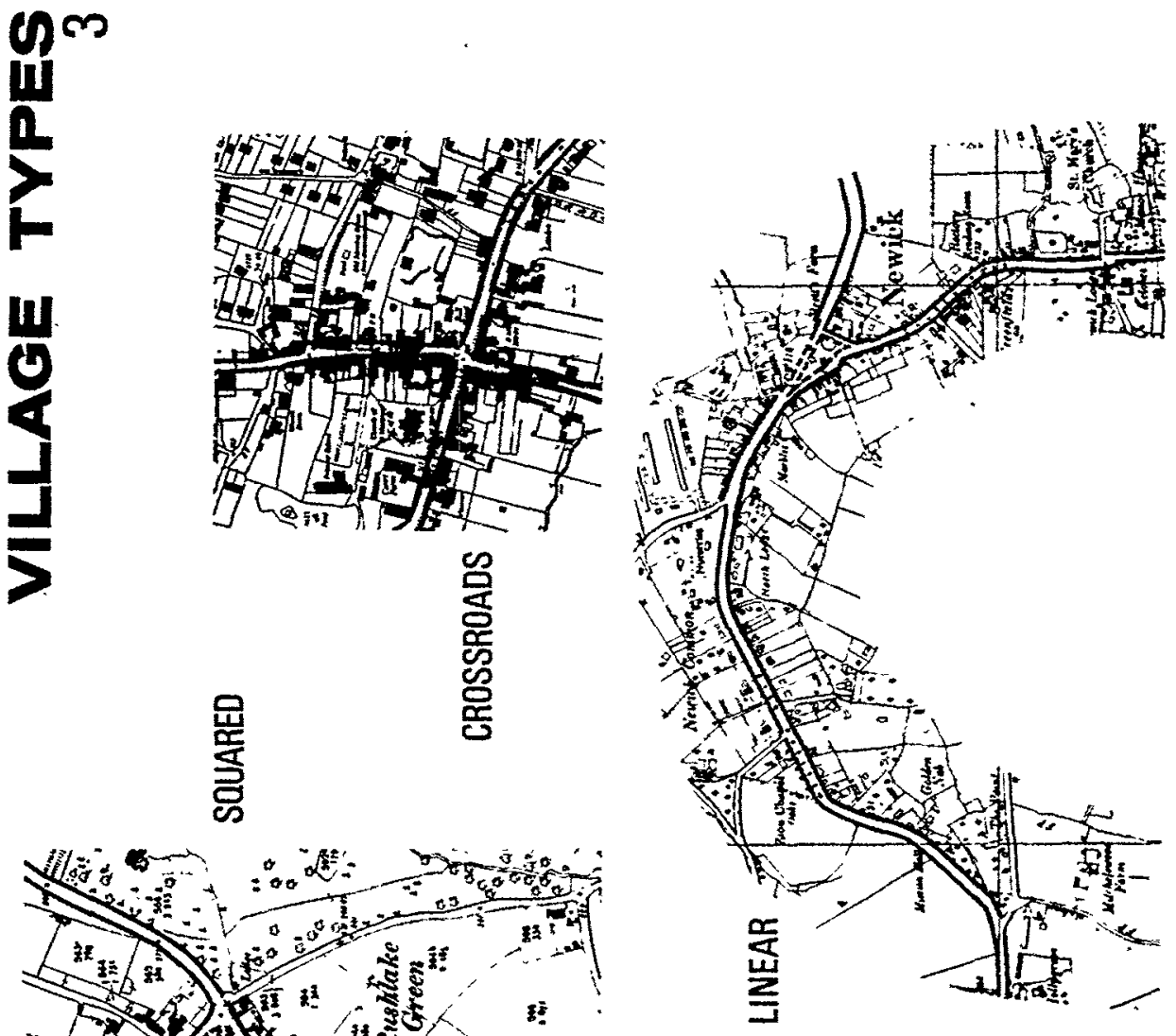

-

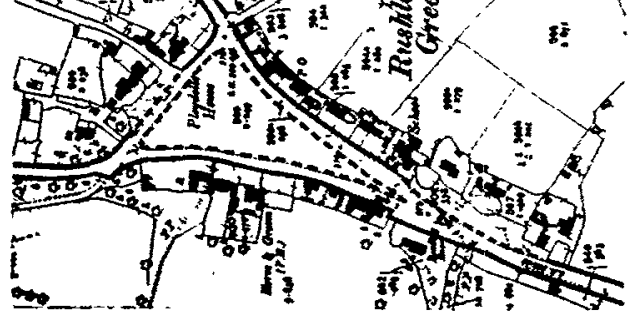




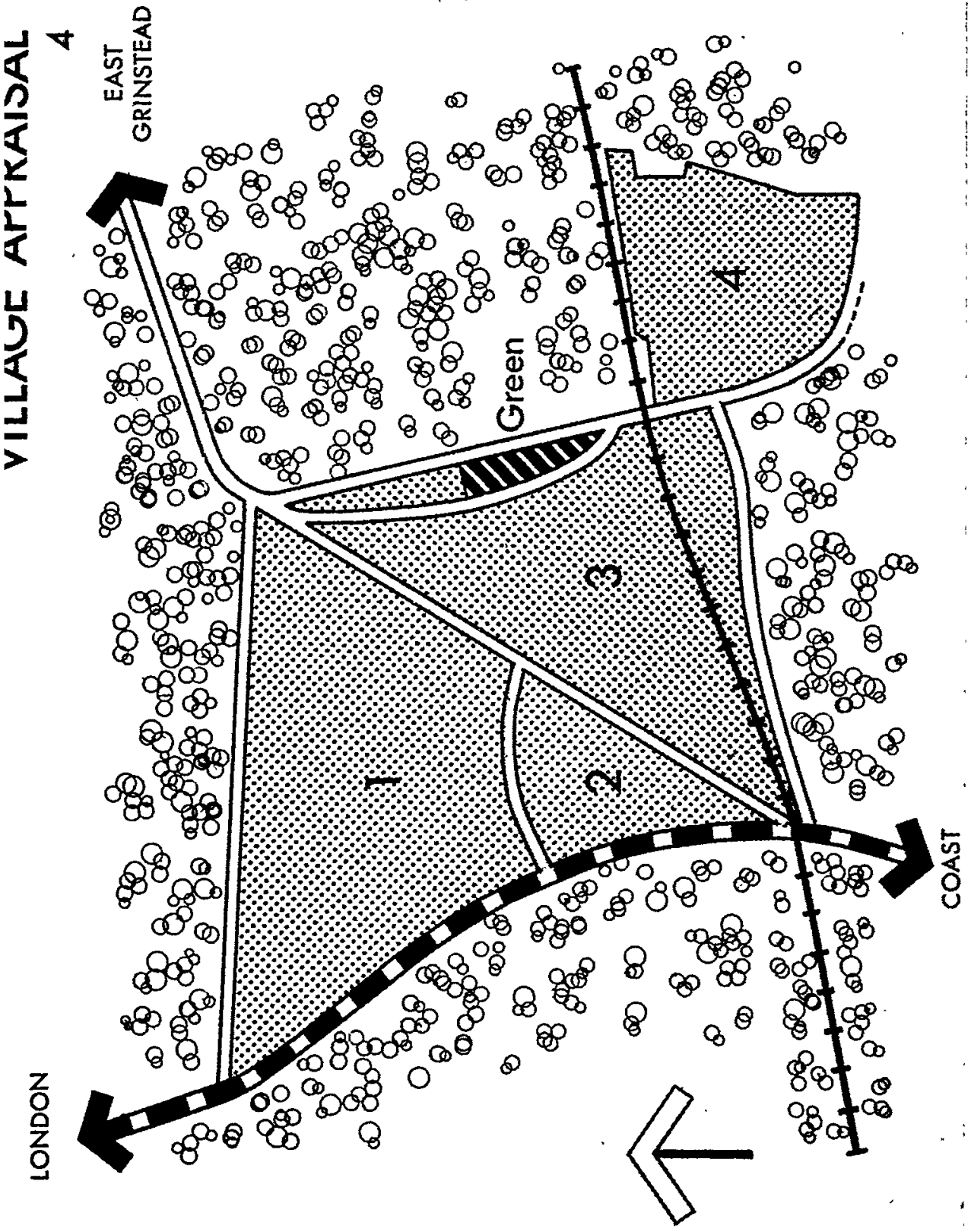




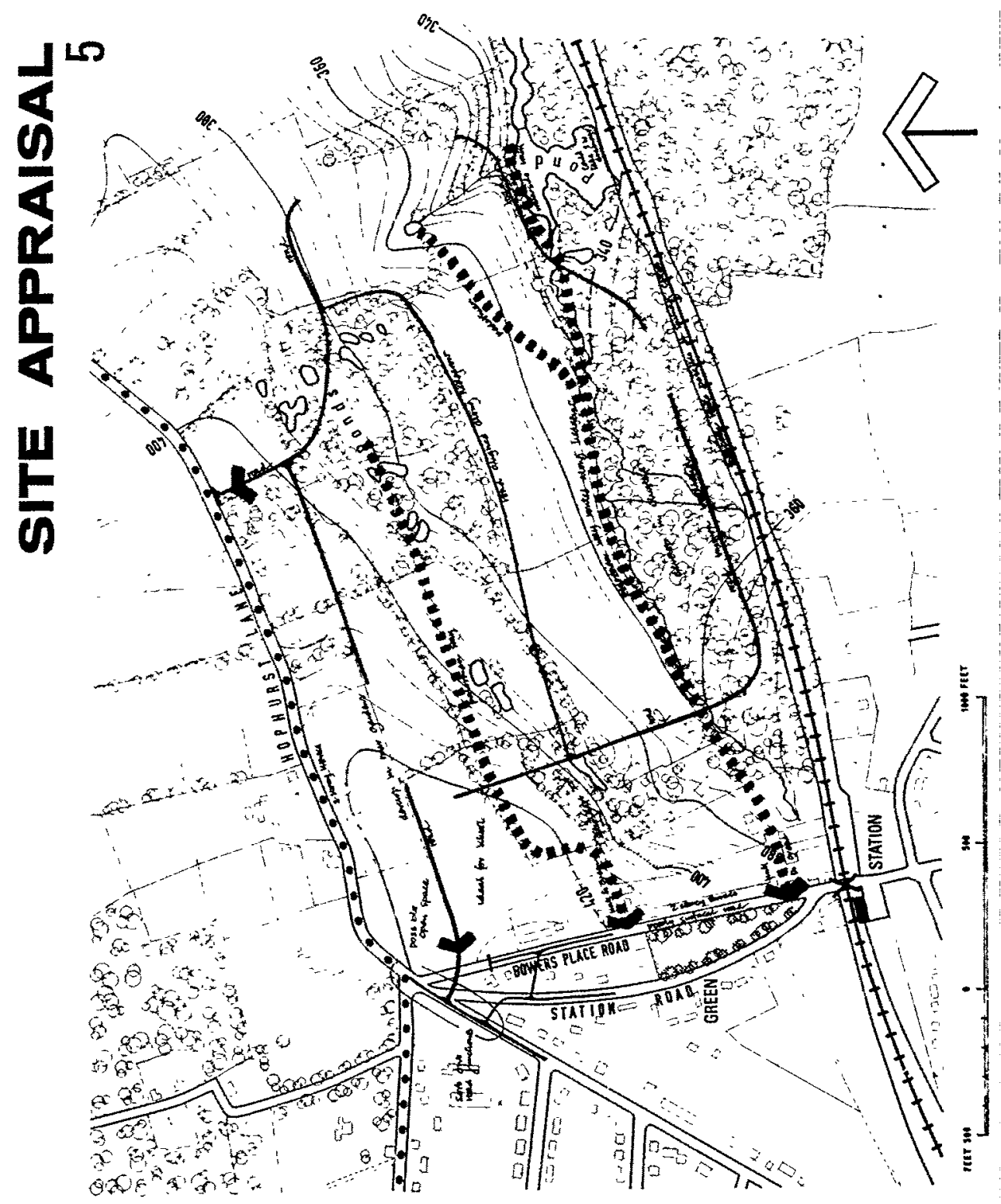




\section{0}

III

I

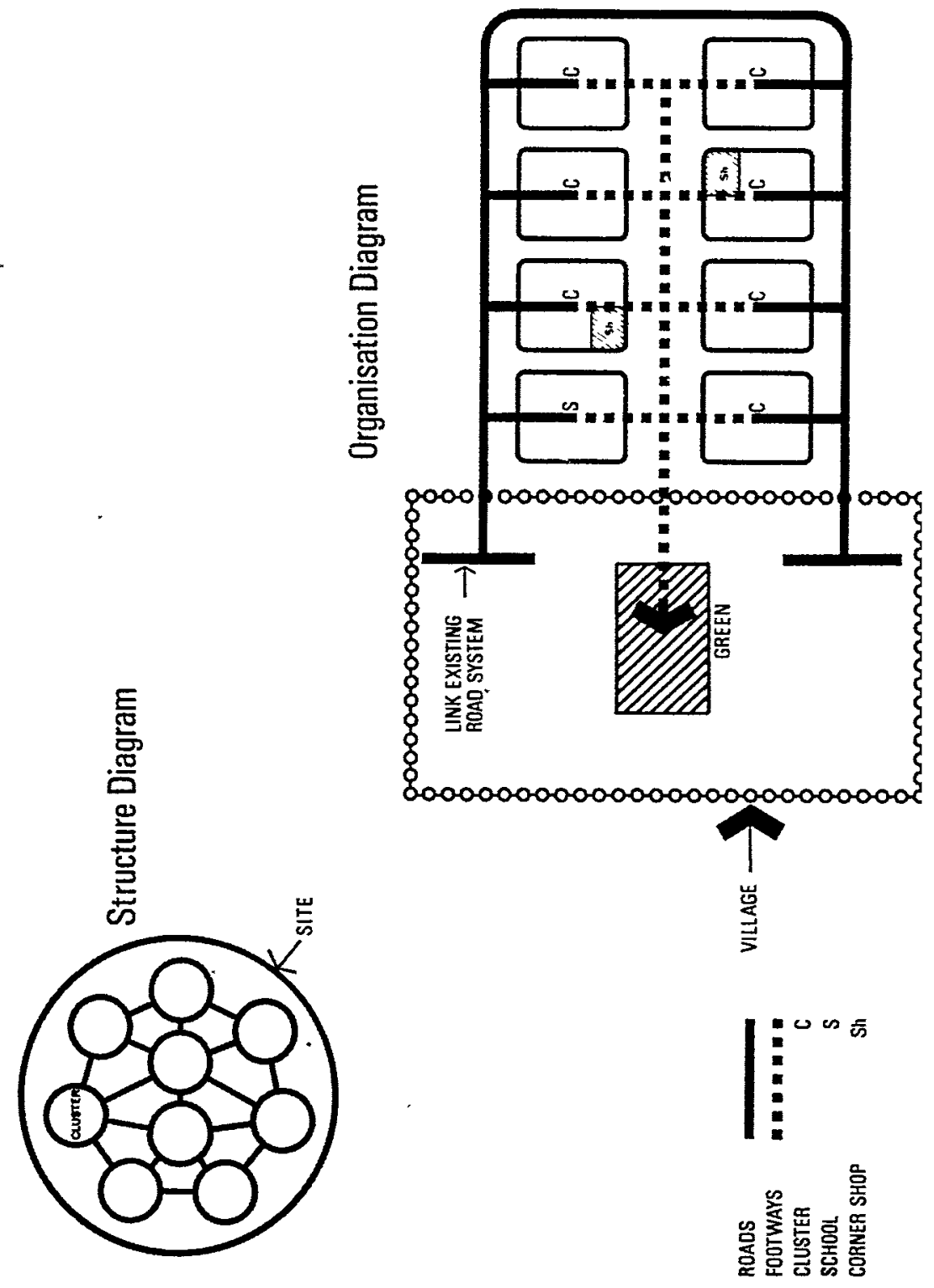




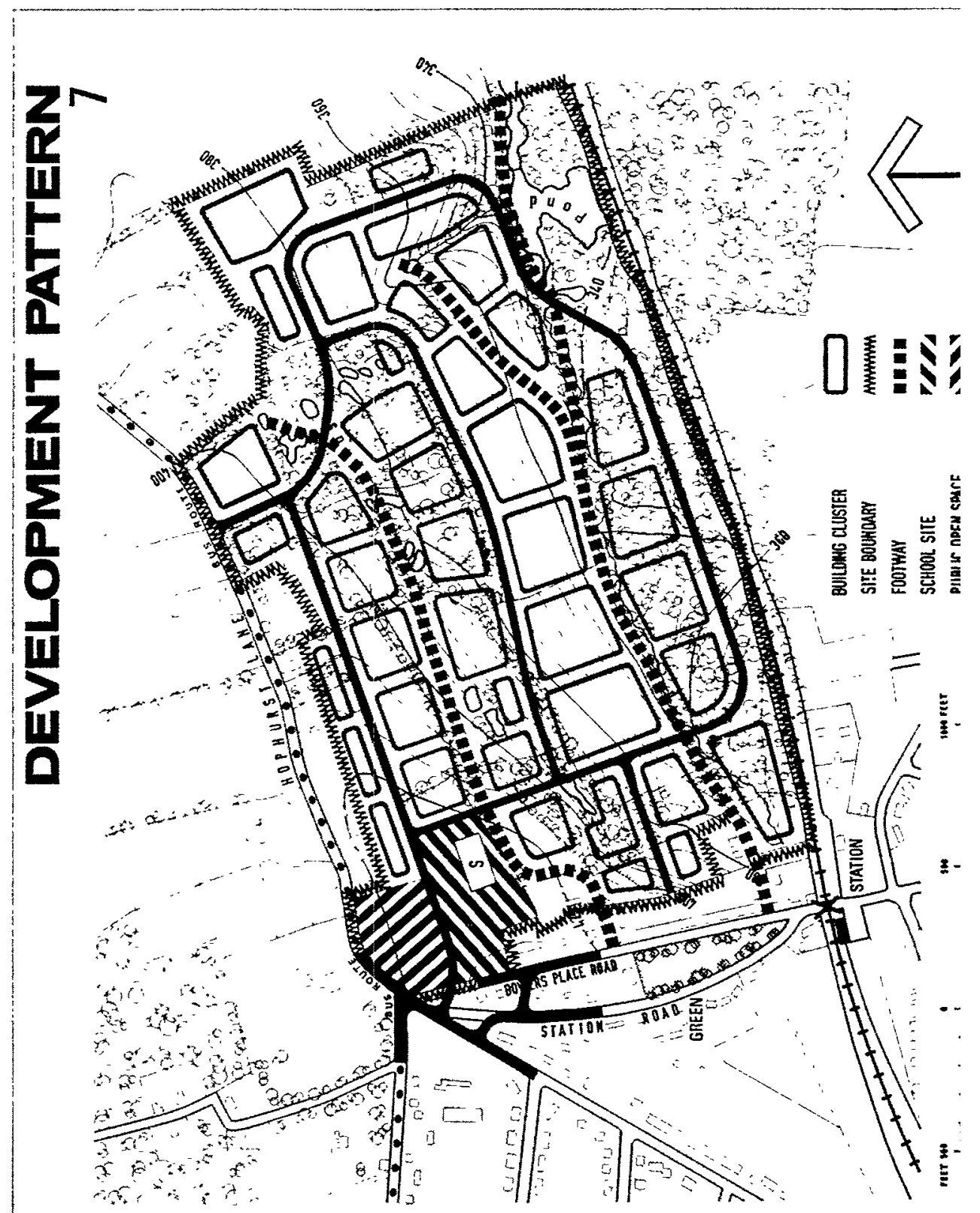

